\title{
3,3'-Diiodothyronine Sulfate Excretion in Maternal Urine Reflects Fetal Thyroid Function in Sheep
}

\author{
SING-YUNG WU, WEN-SHENG HUANG, DELBERT A. FISHER, WARNER H. FLORSHEIM, \\ KENT KASHIWAI, AND DANIEL H. POLK \\ Nuclear Medicine and Medicine Services, Department of Veterans' Affairs Medical Center, Long Beach, \\ California 90822, U.S.A. [S.Y.W., W.H.F.]; Department of Nuclear Medicine, Tri-Service General \\ Hospital, Taipei, Taiwan 100 ROC [W.S.H.]; Quest Diagnostics Nichols Institute, San Juan Capistrano, \\ California 92690, U.S.A. [D.A.F.]; Perinatal Laboratory, Harbor-UCLA Medical Center, Torrance, \\ California 90509, U.S.A. [K.K.]; and Division of Neonatology, Children's Memorial Hospital, \\ Northwestern University Medical School, Chicago, Illinois 60614, U.S.A. [D.H.P.]
}

\begin{abstract}
We have shown that there is significant fetal-to-maternal transfer of sulfated metabolites of thyroid hormone after fetal infusion of a pharmacologic amount of 3,3',5-triiodothyronine $\left(\mathrm{T}_{3}\right.$ ) or sulfated $\mathrm{T}_{3}$ in late pregnancy in sheep (Am J Physiol 277:E915, 1999). The transferred iodothyronine sulfoconjugate, i.e. 3,3'-diiodothyronine sulfate $\left(\mathrm{T}_{2} \mathrm{~S}\right)$, of fetal origin appears in maternal sheep urine. The present study was carried out to assess the contribution of $\mathrm{T}_{2} \mathrm{~S}$ of fetal origin to the urinary pool in ewes. Eighteen date-bred ewes (mean gestational age of $115 \mathrm{~d}$ ) and their twin fetuses were divided into four groups. In group I (control, $n=5$ ), both ewes (M) and their fetuses (F) were sham operated for thyroidectomy (Tx). In group II, the ewes (MTx, $n$ $=4$ ) and, in group III, the fetuses (FTx, $n=4$ ) were subjected to Tx. In group IV (MTx $\cdot \mathrm{FTx}, n=5)$, both the ewe and fetus had Tx. After 10-12 d, fetal and/or maternal hypothyroidism were confirmed by serum thyroxine $(<15 \mathrm{nmol} / \mathrm{L})$ measurements. In addition, we infused radioactive $\mathrm{T}_{3}$ without disturbing the $T_{3}$ pool in three singleton near-term fetuses and assessed the amount of radioactive iodothyronine that appeared in maternal urine (MU). After infusing [ $\left.{ }^{125} \mathrm{I}-\mathrm{3}^{\prime}\right], 3,5-\mathrm{T}_{3}$ via fetal vein to the near-term normal fetuses, radioactive $\mathrm{T}_{2} \mathrm{~S}$ was identified as the major metabolite in MU by HPLC and $\mathrm{T}_{2} \mathrm{~S}$-specific antibody. MU $\mathrm{T}_{2} \mathrm{~S}$ excretion ( $\mathrm{pmol} / \mathrm{mmol}$ creatinine) was significantly
\end{abstract}

\section{ABSTRACT}

reduced by FTx and MTx - FTx but not by MTx. In addition, positive correlations $(p<0.01)$ were found between $\mathrm{MU} \mathrm{T} \mathrm{T}_{2} \mathrm{~S}$ excretion and fetal serum thyroxine and $\mathrm{T}_{3}$ concentrations but not with maternal serum thyroxine or $\mathrm{T}_{3}$ levels. $\mathrm{T}_{2} \mathrm{~S}$ of fetal origin contributes significantly to the MU pool. (Pediatr Res 50: 358-364, 2001)

TH, thyroid hormone

\section{Abbreviations}

$\mathbf{T}_{2} \mathbf{S}, 3,3$ '-diiodothyronine sulfate

Tx, thyroidectomy

$\mathbf{T}_{\mathbf{4}}$, thyroxine

$\mathbf{T}_{\mathbf{3}}$, 3,3',5-triiodothyronine

MU, maternal urinary

D1, type-I iodothyronine deiodinating activity

D3, type-III deiodinating activity

$\mathbf{r T}_{3}, 3,3^{\prime}, 5^{\prime}$, triiodothyronine (reverse $\mathrm{T}_{3}$ )

$\mathbf{T}_{\mathbf{4}} \mathbf{S}$, sulfated thyroxine

$\mathbf{T}_{3} \mathbf{S}$, sulfated $\mathrm{T}_{3}$

$\mathbf{r T}_{3} \mathbf{S}$, sulfated $\mathrm{rT}_{3}$

$\mathbf{T}_{\mathbf{2}}, 3,3$ '-diiodothyronine

cr, creatinine

IST, iodothyronine sulfotransferase
In developing mammals, D1 is low (1) whereas D3 is relatively high in fetal tissues, placenta, and uterus $(2,3)$. As a result, the circulating fetal levels of $\mathrm{T}_{3}$ are reduced and $\mathrm{rT}_{3}$ are elevated (1). In addition, in the mammalian fetus, we observed significantly high concentrations of $\mathrm{T}_{4} \mathrm{~S}, \mathrm{~T}_{3} \mathrm{~S}, \mathrm{rT} \mathrm{T}_{3} \mathrm{~S}$, and $\mathrm{T}_{2} \mathrm{~S}(1$,

Received November 9, 2000; accepted May 9, 2001.

Correspondence and reprint requests: Sing-yung Wu, M.D., Ph.D., Nuclear Medicine and Medical Services (09/151), VA-UCI Medical Center, 5901 E. 7th Street, Long Beach, CA 90822, U.S.A.; e-mail: sing.wu@med.va.gov.

Supported by the Department of Veterans' Affairs, by NIH Grants R15-GM41949 and HD-O4270, and the National Science Council (R.O.C.) NSC 88-2314-B016-035.
4-8). These sulfated iodothyronines are known to be deiodinated mainly by D1 (9), and we have shown that infusion of the ovine fetus with pharmacologic amounts of $\mathrm{T}_{3}(10)$ or $\mathrm{T}_{3} \mathrm{~S}(11)$ resulted in significant fetal-to-maternal transfer of $\mathrm{T}_{3} \mathrm{~S}$ and $\mathrm{T}_{2} \mathrm{~S}$. High concentrations of a $\mathrm{T}_{2} \mathrm{~S}$-like material (Compound $\mathrm{W}$ ) also has been demonstrated in the serum and urine of pregnant women, and the levels of Compound $\mathrm{W}$ increase with the progression of pregnancy and peak shortly before parturition (12). Further evidence suggests that Compound $\mathrm{W}$ is derived from thyroid hormones of fetal origin $(13,14)$, and we have suggested that it may serve as a marker for fetal thyroid function. 
There is evidence that the diiodothyronines $\left(3,3^{\prime}-\mathrm{T}_{2}\right.$ and $3,5-\mathrm{T}_{2}$ ) may be biologically active, stimulating mitochondrial thermogenesis $(15,16)$. These data suggest that sulfoconjugation of $T_{2}$ and other iodothyronines may serve the following functions: 1) to accelerate degradation and excretion of $\mathrm{TH}$ and their derivatives; 2) to provide a reservoir for TH such as $\mathrm{T}_{3}$ $(13,17,18)$ and metabolites including $\mathrm{rT}_{3}(19)$ and $\mathrm{T}_{2}(15,16)$ that can be recovered from these respective sulfated derivatives by sulfatase in selected tissues; 3) to provide via further accelerated deiodination a source of iodine for new hormone synthesis; and 4) to facilitate fetal-to-maternal transfer of $\mathrm{T}_{3} \mathrm{~S}$ metabolites, which may serve to maintain the low serum $T_{3}$ levels in late gestation in precocial species. Additionally, $\mathrm{T}_{2} \mathrm{~S}$ of fetal origin may serve as a noninvasive marker in maternal serum and urine for fetal thyroid function in utero. To further document this possibility, we conducted the present study to measure the contribution of $\mathrm{T}_{2} \mathrm{~S}$ of fetal origin to the urinary pool in ewes and to assess the correlation between fetal $\mathrm{TH}$ concentration and the amount of $\mathrm{T}_{2} \mathrm{~S}$ excreted in maternal urine.

\section{METHODS}

Animal preparation. Western mixed-breed time-dated pregnant ewes with twin pregnancies were obtained from the Nebeker Ranch (Lancaster, CA, U.S.A.) and acclimated to our laboratory conditions and food. Animals were studied in four groups. In group I $(n=5)$, both the ewes and fetuses were sham-operated for Tx. In group II $(n=4)$, the ewes and, in group III $(n=4)$, the fetuses were thyroidectomized. In group $\mathrm{IV}$, both ewes and fetuses were thyroidectomized.

The ewes $(113-121 \mathrm{~d}$ gestation, term $=150 \mathrm{~d})$ were sedated (1.2 $\mathrm{mg}$ atropine and $700 \mathrm{mg}$ ketamine intramuscularly), and a continuous infusion of ketamine $(100 \mathrm{mg} / \mathrm{h})$ was started via a jugular venous catheter. After local anesthesia of the abdominal wall ( $2 \%$ lidocaine), a midline incision was followed by palpation of the uterus and fetal parts and identification of both fetal heads. A hysterotomy was performed over the fetal necks, and fetal membranes were marsupialized to the skin of the fetal neck, avoiding loss of amniotic fluid. The necks of the twin fetuses were infiltrated with $1 \%$ lidocaine, followed by dissection and complete removal of the thyroid gland (Tx) in groups III and IV. The neck incisions were closed. Sham-operated twin fetuses (groups I and II) were handled in a similar manner except that a sham operation was conducted and the thyroid gland was left intact. The maternal thyroid glands were removed after neck dissection in groups II and IV. In the sham-operated group I and III ewes, the maternal thyroid was left intact after neck dissection. In each group, the ewes were treated for $3 \mathrm{~d}$ postoperatively with oxacillin $(2 \mathrm{~g})$ and gentamicin $(80 \mathrm{mg}$ ) given intramuscularly in divided doses. Ten to $12 \mathrm{~d}$ after the initial operation, the ewes were killed. The $10-12$-d interval from Tx to death was chosen based on the serum half-life of $\mathrm{T}_{4}(24 \mathrm{~h})$ in the ovine fetus (8). All experiments were approved by the Harbor-UCLA Medical Center Animal Use Committee. Maternal urinary samples ( $\sim 50 \mathrm{~mL})$ were obtained through catheter at the end of experiments. Fetal and maternal serum samples were collected at the time of initial operation (sham or Tx) and at the end of experiments.

In a separate experiment involving three pregnant sheep with singleton fetuses, hysterotomy was performed $(131 \pm 1 \mathrm{~d}$ of gestation), and a catheter was inserted in the fetal femoral vein. One week later, outer-ring labeled ${ }^{125} \mathrm{I}_{-} \mathrm{T}_{3}(250 \mu \mathrm{Ci}$, sp act $1300 \mu \mathrm{Ci} / \mu \mathrm{g}$ ) diluted in saline was given in a single bolus via the catheter. Maternal serum and urine samples were collected hourly for $4 \mathrm{~h}$.

Preparation of test serum and urine. Samples were extracted with 2 vol of $95 \%$ ethanol before assay. Preliminary experiments showed that the extraction efficiency for $\mathrm{T}_{2} \mathrm{~S}$ and $\mathrm{T}_{3} \mathrm{~S}$ in serum and urine was 91 to $96 \%$. Final values of $\mathrm{T}_{2} \mathrm{~S}$ and $\mathrm{T}_{3} \mathrm{~S}$ concentration were not corrected for recovery efficiency. The preliminary experiments demonstrated that the immunoreactive $\mathrm{T}_{2} \mathrm{~S}$ and $\mathrm{T}_{3} \mathrm{~S}$ in ethanol extracts of fetal and $\mathrm{MU}$ cochromatographed with the synthetic compounds by HPLC.

$\boldsymbol{T}_{2}, \boldsymbol{T}_{3}, \boldsymbol{T}_{2} \boldsymbol{S}$, and $\boldsymbol{T}_{3} \boldsymbol{S} \boldsymbol{R I} \boldsymbol{A} . \mathrm{T}_{2}, \mathrm{~T}_{2} \mathrm{~S}$, and $\mathrm{T}_{3} \mathrm{~S}$ levels in serum and urine were measured by specific and sensitive RIA methods $(4,10,20)$. Serum and urine samples were extracted with 2 vol of $95 \%$ ethanol (final ethanol concentration, $63 \%$ ) as described previously $(4,10,20)$. The lower limit of detection for $\mathrm{T}_{2}$ was $2 \mathrm{ng} / \mathrm{dL}$. $\mathrm{T}_{2} \mathrm{~S}$ RIA has a lower limit of detection of $2 \mathrm{ng} / \mathrm{dL}(33 \mathrm{pmol} / \mathrm{L})$. Of various $\mathrm{TH}$ analogs studied and known to exist in sheep serum or urine, only $\mathrm{T}_{3} \mathrm{~S}, \mathrm{rT}_{3} \mathrm{~S}$, and $\mathrm{T}_{4} \mathrm{~S}$ cross-react significantly $(3.2,1.4$, and $0.02 \%$, respectively) in the $\mathrm{T}_{2} \mathrm{~S}$ RIA; $\mathrm{T}_{4}, \mathrm{~T}_{3}, \mathrm{rT}_{3}$, and $\mathrm{T}_{2}$ cross-reacted $<0.0001 \%$. The $\mathrm{T}_{2} \mathrm{~S}$ concentrations in serum and urine were corrected for the cross-reactivity of $T_{3} S$. The $T_{3}$ S RIA has a lower limit of detection of $2 \mathrm{ng} / \mathrm{dL}(27 \mathrm{pmol} / \mathrm{L})$. Analog cross-reactivities in the $\mathrm{T}_{3} \mathrm{~S}$ RIA are $\mathrm{T}_{4},<0.001 ; \mathrm{rT}_{3},<0.001 ; \mathrm{T}_{3},<0.001 ; \mathrm{rT}_{3} \mathrm{~S}$, $<0.007$; and $\mathrm{T}_{4} \mathrm{~S}, 3.3 \%$. Serum $\mathrm{T}_{3}$ and $\mathrm{T}_{4}$ were assayed using commercial kits purchased from Diagnostic System Laboratory (Webster, TX, U.S.A.) and Nichols Institute Diagnostics (chemiluminescence assay, San Juan Capistrano, CA, U.S.A.), respectively. The lower limit of detection for $\mathrm{T}_{4}$ was $0.2 \mu \mathrm{g} / \mathrm{dL}$ $(2.6 \mathrm{nmol} / \mathrm{L})$ and for $\mathrm{T}_{3}, 5 \mathrm{ng} / \mathrm{dL}(77 \mathrm{pmol} / \mathrm{L})$.

Identification of $\left.I^{125} I\right]-3,3^{\prime}-T_{2} S$ in maternal sheep urine. Radioactive metabolites were identified in MU extracts of sheep whose fetuses were infused via the fetal femoral vein with $\left[{ }^{125} \mathrm{I}\right]-\mathrm{T}_{3}$. Maternal urine and serum samples were extracted with 2 vol of $95 \%$ ethanol and subsequently lyophilized. The dried extracts were dissolved in $1 \mathrm{~mL}$ of $\mathrm{H}_{2} \mathrm{O}$ and purified using an LH-20 column as previously described (10). After application to an HPLC uBondapak $\mathrm{C}_{18}$ column, the serum extract was eluted isocratically with a mixture of acetonitrile and $0.02 \mathrm{M}$ ammonium acetate, $\mathrm{pH} 4.0$ (22:78 vol/ vol), at a flow rate of $2 \mathrm{~mL} / \mathrm{min}$. Aliquots of eluent in $1-\mathrm{mL}$ fractions were collected, and $100 \mu \mathrm{L}$ of these aliquots with significant radioactivities were subjected to immunoprecipitation with $\mathrm{T}_{2} \mathrm{~S}$-specific antibody.

Source of materials. $3,3^{\prime}-\mathrm{T}_{2}, \mathrm{~T}_{3}$, and $\mathrm{T}_{4}$ were purchased from Henning-Berlin Co. (Berlin, Germany). $\left[{ }^{125} \mathrm{I}\right]-3,3{ }^{\prime}-\mathrm{T}_{2}$ was prepared by radioiodination using the method described previously (21). $\mathrm{T}_{3} \mathrm{~S}$ and $\mathrm{T}_{2} \mathrm{~S}$ were synthesized by the method described previously $(22,23)$. Chlorosulfonic acid, 99\%, was purchased from Aldrich Chemical Co. (Milwaukee, WI, 
U.S.A.). $\left[{ }^{125} \mathrm{I}\right]-\mathrm{T}_{3}$ was purchased from Dupont NEN (Boston, MA, U.S.A.).

Statistical analysis. ANOVA was used for multigroup comparisons. If significant differences were detected, the Dunnett multiple comparison test was used to compare the control or baseline mean and the mean values of other groups (24). Unpaired $t$ test was used only to compare differences between the two groups. Significance was defined as $p<0.05$. Results are reported as the mean \pm SEM.

\section{RESULTS}

Effect of fetal or/and maternal Tx on the amount of $T_{2} S$, $T_{3} S, T_{2}$, and $T_{3}$ in $M U$. As shown in Table 1, maternal or/and fetal Tx resulted in significant decreases in serum $\mathrm{T}_{4}$ levels in ewes or/and fetuses, respectively. A significant reduction in serum $\mathrm{T}_{3}$ concentrations occurred in ewes but not in lambs after respective $T x$.

$\mathrm{MU} \mathrm{T}_{2} \mathrm{~S}$ excretion ( $\mathrm{pmol} / \mathrm{mmol} \mathrm{cr}$ ) was significantly reduced by fetal Tx and by combined maternal and fetal Tx $(489 \pm 31$ and $340 \pm 39$, respectively, versus sham control, $778 \pm 52, p$ $<0.05)$ but not by maternal Tx $(742 \pm 40, p>0.05)$ (Table 2). In addition, positive correlations were found between $\mathrm{MU}$ $\mathrm{T}_{2} \mathrm{~S}$ excretion and fetal serum $\mathrm{T}_{4}$ and $\mathrm{T}_{3}(R=0.796, p<0.001$ and $R=0.547, p<0.01$, respectively) concentrations but not maternal serum $T_{4}$ or $T_{3}$ concentrations (Fig. 1). A significant decrease in urinary $\mathrm{T}_{3} \mathrm{~S}$ excretion was observed after either maternal or fetal Tx or both, and there was a positive correlation $(R=0.596, p<0.01)$ between the amount of maternal $\mathrm{T}_{3} \mathrm{~S}$ excretion (pmol/mmol cr) and $\mathrm{T}_{4}$ levels in maternal serum but weakly positive with $\mathrm{T}_{3}$ and $\mathrm{T}_{4}$ levels in fetal serum $(0.025$ $<p<0.05$ ) (Fig. 2). A significant reduction in $\mathrm{T}_{3}$ excretion in MU was observed in ewes after Tx, but this was not the case after fetal Tx (group III) (Table 2).

Effect of fetal or/and maternal Tx on the maternal and fetal $T_{2} S$ and $T_{3} S$ concentrations in serum. Fetal serum $\mathrm{T}_{2} \mathrm{~S}$ levels were reduced after fetal Tx as well as maternal Tx (Table $3)$. However, the $T_{2} S$ levels in group II were not significantly different between prematernal $(1835 \pm 165 \mathrm{pmol} / \mathrm{L})$ and postmaternal Tx (Table 3). On the other hand, fetal $\mathrm{T}_{3} \mathrm{~S}$ concentrations were not significantly altered by fetal hypothyroidism (group III in Table 3). There were significant decreases in fetal serum $\mathrm{T}_{3} \mathrm{~S}$ levels after maternal Tx (group II) and after combined maternal and fetal Tx (group IV). Maternal serum $\mathrm{T}_{2} \mathrm{~S}$ and $\mathrm{T}_{3} \mathrm{~S}$ concentrations were reduced only in group IV in which both the ewe and fetuses were thyroidectomized.
Recovery of radioactivity in $M U$ and serum after fetal

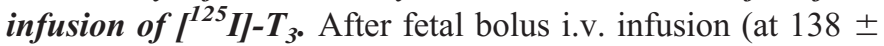
$1 \mathrm{~d}$ gestation) with $\left[{ }^{125} \mathrm{I}\right]-\mathrm{T}_{3}$, hourly $\mathrm{MU}$ and serum samples were collected. After $4 \mathrm{~h}$, the cumulative radioactivity recovered in MU represented $19 \pm 1.5 \%(\mathrm{~N}=3)$ of the infusion dose. As shown in Figure 3, a mean of $43.6 \pm 5.3 \%$ of the total radioactivity recovered in $\mathrm{MU}$ was $\mathrm{T}_{2} \mathrm{~S}$ during the first hour. Thereafter, the proportion of urinary radioactivity as $\mathrm{T}_{2} \mathrm{~S}$ gradually decreased to a mean of $20.9 \pm 0.3 \%$ during the fourth hour. Confirmation of the identity of the $\mathrm{MU} \mathrm{T}_{2} \mathrm{~S}$ peak was determined by both its HPLC retention time (identical to that of known $\left[{ }^{125} \mathrm{I}\right]-3,3^{\prime}-\mathrm{T}_{2} \mathrm{~S}$ standard) and by immunoprecipitation with $\mathrm{T}_{2} \mathrm{~S}$-specific antibody. In addition, immunoreactive $\mathrm{T}_{2} \mathrm{~S}$ in ethanol extracts of MU cochromatographed with the synthetic compound by HPLC (results are not shown). One minor HPLC peak at 15 min cochromatographed with synthetic $\mathrm{T}_{3} \mathrm{~S}$. There was another minor HPLC peak at $18 \mathrm{~min}$ in which total radioactivity increased between the first and fourth hours (Fig. 3). Other minor peaks at $31 / 2$ and 10 min contained radioactivities that remained essentially constant. Radioactivity in the free iodine peak increased from a mean of $39.1 \pm 5.6 \%$ in the first hour to $57.6 \pm 3.2 \%$ at the fourth hour.

\section{DISCUSSION}

In recent reported studies, we demonstrated that there is significant fetal-to-maternal transfer of sulfated metabolites of $\mathrm{TH}$ after fetal infusion of relatively large amounts of $\mathrm{T}_{3}$ or $\mathrm{T}_{3} \mathrm{~S}$ in late pregnancy in sheep $(10,11)$. The transferred iodothyronine sulfoconjugates (i.e. $\mathrm{T}_{2} \mathrm{~S}$ and $\mathrm{T}_{3} \mathrm{~S}$ ) of fetal origin appear in MU. The significant amount of $\mathrm{T}_{3} \mathrm{~S}$ of fetal origin found in MU was apparently a result of infusing a pharmacologic dose of $\mathrm{T}_{3}$ that was more than 20 times the fetal daily production rate of $T_{3}(10)$. In the present study, we infused radioactive $T_{3}$ into the fetal circulation without altering the $\mathrm{T}_{3}$ pool and demonstrated $\mathrm{T}_{2} \mathrm{~S}$ but not $\mathrm{T}_{3} \mathrm{~S}$ as the major sulfoconjugate of fetal origin in MU. This would represent a more physiologic state in assessing fetal-to-maternal transfer. In addition, maternal excretion of $\mathrm{T}_{2} \mathrm{~S}$ was reduced after fetal but not maternal Tx. Furthermore, strong positive correlations were found between $\mathrm{MU} \mathrm{T}_{2} \mathrm{~S}$ excretion $\left(\mathrm{pmol} / \mathrm{mmol} \mathrm{cr}\right.$ ) and fetal serum $\mathrm{T}_{3}$ and $\mathrm{T}_{4}$ concentrations but not with maternal serum $\mathrm{T}_{3}$ or $\mathrm{T}_{4}$ levels. We could not explain that maternal serum $\mathrm{T}_{2} \mathrm{~S}$ levels are the same in either maternal (group II) or fetal (group III) Tx and not significantly reduced compared with the shamoperation control (group I). It is speculated that rapid renal

Table 1. Maternal and fetal serum $T_{4}$ and $T_{3}$ concentrations before and at end of study

\begin{tabular}{|c|c|c|c|c|c|c|c|c|c|c|c|c|}
\hline \multirow[b]{3}{*}{ Group } & \multirow[b]{3}{*}{$n$} & \multirow{2}{*}{\multicolumn{2}{|c|}{$\begin{array}{c}\text { Gestational age }(\mathrm{d}) \\
\text { Maternal }\end{array}$}} & \multicolumn{5}{|c|}{ Serum $\mathrm{T}_{4}(\mathrm{nmol} / \mathrm{L})$} & \multicolumn{4}{|c|}{ Serum $T_{3}(\mathrm{nmol} / \mathrm{L})$} \\
\hline & & & & \multicolumn{2}{|c|}{ Maternal } & \multirow[b]{2}{*}{$n$} & \multicolumn{2}{|c|}{ Fetal } & \multicolumn{2}{|c|}{ Maternal } & \multicolumn{2}{|c|}{ Fetal } \\
\hline & & Surgery & End & Start & End & & Start & End & Start & End & Start & End \\
\hline II & 4 & $115(0.3)$ & $126(0.3)$ & $82(8)$ & $6.5(0.9)^{*}$ & 8 & $125(8)$ & $147(5)$ & $0.9(0.2)$ & $0.3(0.2)^{*}$ & $0.25(0.03)$ & $0.14(0.02)$ \\
\hline III & 4 & $114(0.3)$ & $125(0.3)$ & $103(8)$ & $124(8)$ & 8 & $117(5)$ & $13(2.0)^{*}$ & $1.2(0.2)$ & $1.1(0.1)$ & $0.20(0.05)$ & $0.10(0.02)$ \\
\hline IV & 5 & $117(1.2)$ & $129(2.0)$ & $80(8)$ & $7.8(0.5)^{*}$ & 10 & $142(6)$ & $6.1(0.8)^{*}$ & $1.1(0.2)$ & $0.3(0.1)^{*}$ & $0.18(0.05)$ & $0.10(0.02)$ \\
\hline
\end{tabular}

Group I: both mothers and fetuses were sham operated; group II: maternal Tx only; group III: fetal Tx only; group IV: both mothers and fetuses had Tx. Data are presented as means (SE).

$* p<0.05$ (vs starting baseline value). 
Table 2. Effect of fetal $(F)$ orland maternal $(M) T x$ on the amount of $T_{2} S, T_{3} S, T_{2}$ and $T_{3}$ in $M U$

\begin{tabular}{|c|c|c|c|c|c|c|}
\hline Group & $n$ & Surgery & \multicolumn{4}{|c|}{ (pmol/mmol creatinine) } \\
\hline I & 5 & Sham & $778(52)$ & $435(38)$ & $358(74)$ & $512(41)$ \\
\hline II & 4 & MTx & $742(40)$ & $264(22)^{* *}$ & $255(61)$ & $138(29)^{* *}$ \\
\hline IV & 5 & MTx $\cdot$ FTx & $340(39)^{* *}$ & $102(18)^{* *}$ & $174(69)$ & $85(38)^{* *}$ \\
\hline
\end{tabular}

$* p<0.05, * * p<0.01 v$ group I, sham-operated control group. Data are presented as means (SE).

MU samples were collected $11-12 \mathrm{~d}$ after sham or Tx surgery.


Figure 1. Correlation between $\mathrm{MU} \mathrm{T}_{2} \mathrm{~S}$ excretion (pmol/mmol cr) and the corresponding $(A)$ fetal serum $\mathrm{T}_{4}$ concentrations (nmol/L), $(B)$ fetal serum $\mathrm{T}_{3}$ concentrations (pmol/L), $(C)$ maternal serum $\mathrm{T}_{4}$, and $(D)$ maternal serum $\mathrm{T}_{3}$ concentrations. $\square$ represents group I, control; $\bullet$, group II, maternal Tx; $\diamond$, group III, fetal Tx; and $\mathbf{\Delta}$ group IV, maternal and fetal Tx.

clearance of $\mathrm{T}_{2} \mathrm{~S}$ may play a role. Although fetal serum $\mathrm{T}_{2} \mathrm{~S}$ levels were significantly decreased in group II compared with group I, the decreases were not significantly different from the baseline values. On the other hand, $\mathrm{MU} \mathrm{T}_{3} \mathrm{~S}$ excretion was reduced after either maternal or fetal Tx. Using $2 \times 2$ factorial analysis in SPSS with fetal Tx and maternal $\mathrm{Tx}$ as the two factors (25), we assessed effects of fetal Tx (group I and II versus III and IV) and of maternal Tx (group I and III versus II and IV). An additive effect of fetal Tx was found to be significant in $\mathrm{MU} \mathrm{T}_{2} \mathrm{~S}$ and $\mathrm{T}_{3} \mathrm{~S}$ excretion as well as fetal serum 

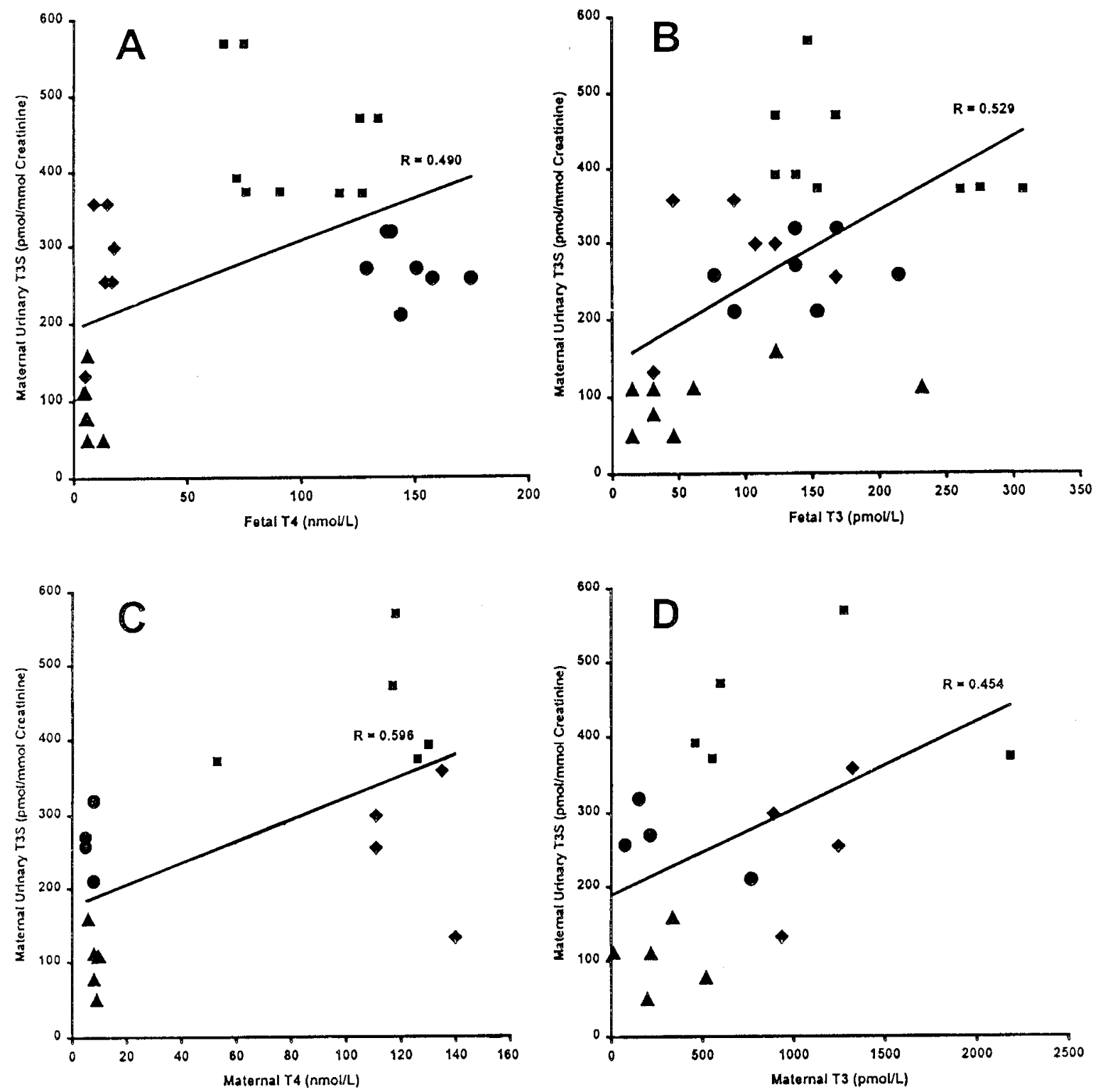

Figure 2. Correlation between $\mathrm{MU} \mathrm{T}_{3} \mathrm{~S}$ excretion (pmol/mmol cr) and the corresponding $(A)$ fetal serum $\mathrm{T}_{4}$ concentrations, $(B)$ fetal serum $\mathrm{T}_{3}$ concentrations, $(C)$ maternal serum $\mathrm{T}_{4}$ concentrations, and $(D)$ maternal serum $\mathrm{T}_{3}$ concentrations. The respective units of concentration and symbols are shown in Figure 1.

Table 3. Effect of fetal or/and MTx on the $T_{2} S$ and $T_{3} S$ concentrations in maternal and fetal sera

\begin{tabular}{|c|c|c|c|c|c|c|c|c|c|c|c|c|}
\hline \multirow[b]{3}{*}{ Group } & \multirow[b]{3}{*}{$n$} & \multicolumn{6}{|c|}{$\mathrm{T}_{2} \mathrm{~S}(\mathrm{pmol} / \mathrm{L})$} & \multicolumn{5}{|c|}{$\mathrm{T}_{3} \mathrm{~S}(\mathrm{pmol} / \mathrm{L})$} \\
\hline & & \multicolumn{2}{|c|}{ Maternal } & \multirow[b]{2}{*}{$n$} & \multicolumn{2}{|c|}{ Fetal } & \multirow[b]{2}{*}{$n$} & \multicolumn{2}{|c|}{ Maternal } & \multirow[b]{2}{*}{$n$} & \multicolumn{2}{|c|}{ Fetal } \\
\hline & & Start & End & & Start & End & & Start & End & & Start & End \\
\hline II & 4 & $446(55)$ & $463(40)$ & 8 & $1835(165)$ & $1901(264)^{*}$ & 4 & $342(64)$ & 333 (37) & 8 & 917 (114) & $465(67)^{*}$ \\
\hline III & 4 & $380(36)$ & $463(73)$ & 8 & 1504 (116) & $1190(149)^{*}$ & 4 & $328(41)$ & $328(137)$ & 8 & $917(75)$ & 725 (130) \\
\hline IV & 5 & $430(26)$ & $264(35)^{*}$ & 10 & $1686(116)$ & $446(66)^{*}$ & 5 & $328(66)$ & $52(14)^{* *}$ & 10 & 889 (66) & $98(18)^{* *}$ \\
\hline
\end{tabular}

Group I, II, III, and IV: see Table I; Data are presented as means (SE).

$* p<0.05, * * p<0.01 v$ s group I sham-operated control.

$\mathrm{T}_{2} \mathrm{~S}$. On the other hand, the additive effect of maternal Tx was found to be significant in maternal serum $\mathrm{T}_{3}$ and $\mathrm{T}_{4}$ as well as MU $T_{3}$ and $T_{3} S$ but not $T_{2} S$. Thus, it appears that the major determinant of the amount of $\mathrm{MU} \mathrm{T}_{2} \mathrm{~S}$ excretion is the fetal thyroid status.
In humans, a precocial species similar to sheep, we found high levels of $\mathrm{T}_{2} \mathrm{~S}$-like material (Compound $\mathrm{W}$ ) in maternal serum (12) and urine (14). Levels increase with the progression of pregnancy, peaking near term at which time a 20 -fold increase in serum levels of this $\mathrm{T}_{2} \mathrm{~S}$-like material is 




Figure 3. Identification of $\left[{ }^{125} \mathrm{I}\right]-3,3^{\prime}-\mathrm{T}_{2} \mathrm{~S}$ by specific antibody and by cochromatographing with synthetic-labeled $\mathrm{T}_{2} \mathrm{~S}$ in urine extract of maternal ewes eluted from HPLC $\left(\mathrm{C}_{18}\right.$ column) isocratically with a mixture of acetonitrile and $0.02 \mathrm{M}$ ammonium acetate, $\mathrm{pH} 4.0(22: 78$, vol/vol), at a flow rate of $2 \mathrm{~mL} / \mathrm{min}$.

found compared with nonpregnant women. Serum levels return to nonpregnant values by 7-10 d postpartum (12). Further clinical studies suggest that Compound $\mathrm{W}$ is derived from $\mathrm{TH}$ of fetal origin, analogous to the present studies in sheep, and can be a practical marker for fetal thyroid function (13).

The mechanism and site(s) of fetal-to-maternal transfer of $\mathrm{T}_{2} \mathrm{~S}$ are unclear. 3,3'- $\mathrm{T}_{2}$ is a metabolite derived from both inner-ring deiodination of $\mathrm{T}_{3}$ and outer-ring deiodination of $\mathrm{rT}_{3}$. In addition, $\mathrm{T}_{2}$ is a preferred substrate for IST in rat liver (26) and uterus (27). $\mathrm{T}_{2} \mathrm{~S}$ can also be formed at an accelerated rate from further deiodination of $\mathrm{T}_{3} \mathrm{~S}$ and $\mathrm{rT}_{3} \mathrm{~S}$, both of which are abundant in the fetal circulation and biologic fluids in lambs late in gestation $(6,8,28,29)$. It is likely that there is an increasing production of $\mathrm{T}_{2} \mathrm{~S}$ in precocial species fetuses in late gestation as the hypothalamic-pituitary-thyroid axis matures. In addition to $\mathrm{T}_{2} \mathrm{~S}$ formation, an active mechanism to convert fetal $\mathrm{T}_{4}$ to $\mathrm{rT}_{3}$, $\mathrm{T}_{2}, \mathrm{~T}_{4} \mathrm{~S}, \mathrm{rT}_{3} \mathrm{~S}, \mathrm{~T}_{3} \mathrm{~S}$, and $\mathrm{T}_{2} \mathrm{~S}$ may be important to normal fetal development, especially in late gestation. $T_{2}$ has been shown to stimulate mitochondrial respiration in various rat tissues $(15,16)$, and it is possible that a tight regulation of $\mathrm{T}_{2}$ concentration by sulfation and fetal-to-maternal transfer would have physiologic value. Because sulfation is a reversible process, tissue sulfatase enzyme(s) can desulfate $T_{2} S$, converting it back to an active iodothyronine. Thus, the fetal-to-maternal transfer may protect the fetus from excessive mitochondrial thermogenesis stimulated by high fetal concentration of $T_{2}$. $T_{2} S$ species (i.e. $3^{\prime}, 5^{\prime}-T_{2} S$ and 3,5- $T_{2} S$ ) other than $3,3^{\prime}-\mathrm{T}_{2} \mathrm{~S}$ have not been measured.

More recently, a placental IST was detected in the cytosol of sheep cotyledon (Wu SY, unpublished data). Again, $\mathrm{T}_{2}$ was shown to be the preferred substrate for the placental IST in sheep, and we observed significant D3 activity in the cotyledon homogenates (Wu SY, Polk DH, Fisher DA, unpublished observation). The observation that D3 metab- olites, namely $\mathrm{T}_{2}$ and $\mathrm{rT}_{3}$, are the preferred metabolites for the placental IST suggests that D3 may be linked to IST to facilitate fetal-to-maternal transfer of $\mathrm{T}_{2} \mathrm{~S}$. In perfusing the fetal side of guinea pig with TH, Castro et al. (30) found $\mathrm{T}_{3}$ is much more rapidly inner-ring deiodinated than $\mathrm{T}_{4}$. In addition, Rudolph and Heymann (31) have shown in sheep that the placenta received 40 to $50 \%$ of the fetal cardiac output. Furthermore, Sack et al. (32) showed that umbilical cord cutting triggers hypertriiodothyroninemia in the newborn lamb and that the postnatal $\mathrm{T}_{3}$ peak can be delayed until well after the TSH peak by delaying umbilical cord cutting. Recently, Santini et al. (33) found that the placenta may play an important role in maintaining the low serum $\mathrm{T}_{3}$ in fetuses late in gestation. These findings suggest the importance of the placenta in fetal $\mathrm{T}_{3}$ metabolism, and it is possible that fetal-to-maternal transfer of the $\mathrm{T}_{3} \mathrm{~S}$ metabolite (presumably via placenta) can be a further novel mechanism involved in reducing serum $\mathrm{T}_{3}$ concentrations in the fetus.

The present study also revealed another interesting aspect of fetal-maternal TH homeostasis in sheep. In agreement with our previous study, fetal serum levels of $\mathrm{T}_{3} \mathrm{~S}$ were not reduced by fetal hypothyroidism (8). The reason is unclear; the fetal serum $\mathrm{T}_{3} \mathrm{~S}$ level does not correlate with fetal serum $\mathrm{T}_{3}$ or $\mathrm{T}_{4}$ but weakly correlates with maternal serum $\mathrm{T}_{4}$. In contrast, fetal serum $\mathrm{T}_{2} \mathrm{~S}$ levels decreased significantly after fetal $\mathrm{Tx}$ and showed a significant correlation with the low fetal serum $\mathrm{T}_{4}$ concentrations.

In conclusion, we have demonstrated significant fetal-tomaternal transfer of $\mathrm{T}_{2} \mathrm{~S}$ in late gestation in sheep. The present study also suggests that the amount of $\mathrm{T}_{2} \mathrm{~S}$ excretion in maternal sheep urine reflects fetal thyroid status.

Acknowledgments. The authors thank Hien Q. On and Cynthia Simons for their help in the experiments. We also thank Michael N. Lopez for his assistance in biostatistics. 


\section{REFERENCES}

1. Wu SY, Fisher DA, Polk D, Chopra IJ 1991 Maturation of thyroid hormone metabolism. In: Wu SY (ed) Thyroid Hormone Metabolism, Regulation, and Clinical Implications. Blackwell Scientific, Boston, pp 293-320

2. Bates JM, St Germain DL, Galton VA 1999 Expression of profiles of the three iodothyronine deiodinases, $\mathrm{D}_{1}, \mathrm{D}_{2}$, and $\mathrm{D}_{3}$ in the developing rat. Endocrinology 140:844-851

3. Galton VA, Martinez E, Hernandez A, St Germain EA, Bates JM, St Germain DL 1999 Pregnant rat uterus expresses high levels of the type 3 iodothyronine deiodinase. J Clin Invest 103:979-987

4. Chopra IJ, Wu SY, Chua Teco GN, Santini F 1992 A radioimmunoassay for measurement of 3,5,3'-triiodothyronine sulfate studies in thyroidal and non-thyroidal disease, pregnancy, and neonatal life. J Clin Endocrinol Metab 75:189-194

5. Hurd RE, Santini F, Lee B, Naim P, Chopra IJ 1993 A study of the 3,5,3'triiodothyronine sulfation activity in the adult and fetal rat. Endocrinology 133:19511955

6. Polk DH, Reviczky A, Wu SY, Huang WS, Fisher DA 1994 Metabolism of sulfoconjugated thyroid hormone derivatives in developing sheep. Am J Physiol 266:E892-E895

7. Wu SY, Polk DH, Wong S, Reviczky A, Vu R, Fisher DA 1992 Thyroxine sulfate is a major thyroid hormone metabolite and a potential intermediate in the monodeiodination pathways in fetal sheep. Endocrinology 131:1751-1756

8. Wu SY, Polk DH, Huang WS, Reviczky A, Wang K, Fisher DA 1993 Sulfate conjugates of iodothyronines in developing sheep: effect of fetal hypothyroidism. Am J Physiol 265:E115-E120

9. Visser TJ 1994 Sulfation and glucuronidation pathways of thyroid hormone metabolism. In: Wu SY, Visser TJ (eds) Thyroid Hormone Metabolism: Molecular Biology and Alternate Pathways. CRC Press, Boca Raton, pp 85-117

10. Wu SY, Polk DH, Fisher DA, Huang WS, Reviczky A, Chen WL 1995 Identification of $3,3^{\prime}-\mathrm{T}_{2} \mathrm{~S}$ as a fetal thyroid hormone derivative in maternal urine in sheep. Am J Physiol 268:E33-E39

11. Wu SY, Polk DH, Huang WS, Fisher DA 1999 Fetal-to-maternal transfer of 3,3',5triiodothyronine sulfate and its metabolite in sheep. Am J Physiol 277:E915-E919

12. Wu SY, Polk DH, Chen WL, Fisher DA, Huang WS, Yee B 1994 A 3,3'diiodothyronine sulfate cross-reactive compound in serum from pregnant women. $\mathrm{J}$ Clin Endocrinol Metab 78:1505-1509

13. Cortelazzi DP, Morpurgo S, Azmperini P, Fisher DA, Beck-Peccoz P, Wu SY 1999 Maternal compound $\mathrm{W}$ serial measurements in the management of fetal hypothyroidism. Eur J Endocrinol 141:570-578

14. Wu SY, Polk DH, Fisher DA, Huang WS, Beck-Peccoz P, Emerson CH, Kuo SW, Chen WL 1998 Urinary compound W in pregnant women is a potential marker for fetal thyroid function. Am J Obstet Gynecol 178:886-891

15. Lanni A, Moreno M, Lombordi A, Goglia F 1998 3,5-diiodothyronine and 3,5,3'triiodothyronine both improve the cold tolerance of hypothyroid rats, but possibly via different mechanism. Eur J Physiol 436:407-414
16. Moreno M, Lanni A, Lombardi A, Goglia F 1997 How the thyroid controls metabolism in the rat: different roles for triiodothyronine and diiodothyronine. J Physiol 505:529-538

17. Chopra IJ, Santini F, Wu SY, Hurd RE 1994 The role of sulfation and desulfation in thyroid hormone metabolism. In: Wu SY, Visser TJ (eds) Thyroid Hormone Metabolism: Molecular Biology and Alternate Pathways. CRC Press, Boca Raton, pp $119-138$

18. Santini F, Hurd RE, Lee B, Chopra IJ 1993 Thyromimetic effects of 3,5,3'triiodothyronine sulfate $\left(\mathrm{T}_{3} \mathrm{~S}\right)$ in hypothyroid rat. Endocrinology 133:105-110

19. Leonard JL, Farwell A 1997 Thyroid hormone-regulated actin polymerization in brain. Thyroid 7:147-151

20. Wu SY, Chopra IJ, Nakamura Y, Solomon DH, Bennett LR 1976 A radioimmunoassay for measurement of 3,3'-diiodothyronine $\left(\mathrm{T}_{2}\right)$. J Clin Endocrinol Metab 43:682685

21. Nakamura Y, Chopra IJ, Solomon DH 1977 Preparation of high specific activity radioactive iodothyronines and their analogues. J Nucl Med 18:1112-1115

22. Eelkman-Rooda SJ, Kaptein E, Vanloon MAC, Visser TJ 1988 Development of a radioimmunoassay for triiodothyronine sulfate. J Immunoassay 9:125-134

23. Mol JA, Visser TJ 1985 Synthesis and some properties of sulfate esters and sulfamates of iodothyronines. Endocrinology 117:1-7

24. Kirk RE 1982 Experimental Design, 2nd Ed. Brooks/Cole, Belmont, pp 112-114

25. Maxwell SE, Delaney HD 1990 Designing Experiments and Analyzing Data. Brooks/ Cole Publishing Co., Pacific Groove, pp 242-292

26. Kaptein E, Van Haasteren GAC, Linkels E, DeGreef WJ, Visser TJ 1997 Characterization of iodothyronine sulfotransferase activity in rat liver. Endocrinology 138:5136-5143

27. Wu SY, Huang WS, Fisher DA, Florsheim WH, St Germain DL, Galton VA 2000 Iodothyronine sulfotransferase activity in rat uterus during gestation. Pediatr Res 48:847-851

28. Wu SY, Huang WS, Polk DH, Florsheim WH, Green WL, Fisher DA 1992 Identification of thyroxine-sulfate $\left(\mathrm{T}_{4} \mathrm{~S}\right)$ in human serum and amniotic fluid by a novel $\mathrm{T}_{4} \mathrm{~S}$ radioimmunoassay. Thyroid 2:101-105

29. Wu SY, Huang WS, Polk DH, Chen WL, Reviczky A, Williams III J, Chopra IJ, Fisher DA 1993 The development of a radioimmunoassay for reverse triiodothyronine sulfate in human serum and amniotic fluid. J Clin Endocrinol Metab 76:1625-1630

30. Castro MI, Braverman LE, Alex S, Wu CF, Emerson CH 1985 Inner-ring deiodination of 3,5,3'-triiodothyronine in the in situ perfused guinea pig placenta. J Clin Invest 76:1921-1926

31. Rudolph AM, Heymann MA 1970 Circulatory changes during growth in the fetal lamb. Circ Res 26:289-296

32. Sack J, Beaudry M, Delamater PV, Oh W, Fisher DA 1976 Umbilical cord cutting triggers hypertriiodothyroninemia and nonshivering thermogenesis in the newborn lamb. Pediatr Res 10:169-175

33. Santini F, Chiovato L, Ghirri P, Lapi P, Mammoli C, Montanelli L, Scartabelli G, Ceccarini G, Coccoli L, Chopra IJ, Boldrini A, Pinchera A 1999 Serum iodothyronine in the human fetus and the newborn: evidence for an important role of placenta in fetal thyroid hormone homeostasis. J Clin Endocrinol Metab 84:493-498 